\title{
Psychodynamic Perspective of Organizational Change
}

Prof. Adela Barabasz Wrocław University Of Economics, Department Of Management Systems Design
1. Introduction - The basic assumptions of the psychodynamic approach

Although psychoanalytic theories do not belong to the mainstream of organization research, there has been a growing recognition of the input of psychoanalysis into the understanding of group processes, the mechanisms of functioning of whole organizations and societies (see: Freud 1993, Bion 1961, Gabriel 1983, Kernberg 1998, Miller 1993, Vansina 2013, Brunning 2012, Seviers 2009, Armstrong, Rustin 2015, and many others).

Psychoanalytic theories explain the intraand interpsychic phenomena reaching deep into the mental world of individuals. They describe not only a person's inner world, but also the mechanisms of functioning of groups and the mechanisms that explain the functioning of organizations, which are treated holistically, not only as actually existing objects, but also as internalized objects in the minds of organization members. In research on organization behaviour, there is assumed the need to reach beyond the level of conscious declaration and undertakes the challenge to seek the deep, underlying motives that trigger the actions of individuals (organization members). 
What is one of the key phenomena examined within the psychodynamic approach (that is one based on the psychoanalytic paradigm, taking into account the systemic conditions of an organization's functioning), are the superiorsubordinate relations and identification of the mechanisms responsible for the behaviour of organization members, who act not only on a level accessible to rational cognition, but also identification of the mechanisms that operate beyond the sphere of consciousness.

Psychodynamic understanding of organizational change, which usually evokes strong emotions, as any change tends to interfere with the sense of security and arouses anxiety, and as a consequence, resistance of organization members, is particularly useful; not only in cognitive terms, but also due to the possibility to apply the conclusions in management practice. It enables comprehension of the difficult, often unpredictable, even irrational decisions and surprising choices of managers, as well as frequently surprising reactions of their reports; it helps to discover the anxieties and fears, but also the desires and hopes of organization members, showing their nature and intensity at different areas of the organization. This approach enables better comprehension of the difficult, often unpredictable, and sometimes irrational decisions and choices of managers. These are frequently accompanied by unexpected, often disconcerting reactions of their reports. Not only do concepts stemming from psychoanalytic thinking help to discover the sources of the anxieties and fears, but also the nature of desires, expectations and hopes, which are triggered in organization members in relation to the planned change. Thanks to a better, more adequate understanding of the inner world of organization members, it becomes possible to manage the complex process of organizational change more effectively, at least in those aspects that require direct and full involvement of organization members.

Application of the psychoanalytic paradigm assumes focusing on interpersonal relations, both in the dimension directly accessible to cognition and taking into account the roles of unconscious phenomena and processes that determine the behaviour of organization members, both subordinates and superiors. The paradigm helps to examine, among others, the complementary roles that members of management teams take with respect to one another; it helps to identify the self-destructive and self-penalizing expectations and beliefs, negative self-esteem and inadequate self-perception, as well as the models of behaviour which, useful in the past, may be 'uneconomic,' or even dysfunctional in the present situation. 
M. Kets de Vries and D. Miller (1986) argue that the psychoanalytic paradigm enables a richer, more complex and deeper characterization of organizational behaviour than the approaches proposed by representatives of the other currents of research on organizational behaviour. For it is believed that the current of Human Relations focuses on the impact of specific needs on the behaviour of organization members. Explanation of the behaviour of organization members through determination of their features and characteristics belongs to the behavioural-cognitive approach. Researchers who represent that current concentrate on individual dispositions of leaders or key people in an organization. Personality features and cognitive attributes that are particularly readily measured are those that are aimed at determining the impact on such behaviours as risk proneness, manner of making decisions, or the preferred management style.

Reference to the psychoanalytical theories enables identification of intrapsychic and inter-group mechanisms, assuming that it is them rather than individual characteristics what determines the manifested behaviours. This approach enables understanding of both the automatic and reflective motives behind choices, anxieties and hopes, experienced by organization members.

At the same time, in accordance with the assumption adopted by representatives of this approach, which applies also to the description of the functioning of groups and organizations, those contents (thoughts, emotions) from an individual's inner world that remain in conflict are most often rejected, suppressed or denied (see Loewald 1980, Czander 1993, Hirschhorn 1988, de Board 2003, Gabriel 2004). This happens because an inner conflict between elements of an individual's mental world leads to an increase in the level of anxiety, which in turn triggers reduction of the anxiety through defence mechanisms.

This paper presents the key concepts stemming from the psychoanalytic approach to organization and management. Its main aim is to discuss the major categories and concepts derived from psychoanalytic theories, which pertain to the issues related to organizational change. Theoretical considerations are complemented by presentation of the data collected during interviews with managers from the examined organization and identification of the defence mechanisms of representatives of the organization's management.

\section{The importance of emotions and defence mechanisms in an organization}

Already the early research by K. Lewin and L. Festinger showed that group processes cannot be fully comprehended without factoring in the emotions. 
They lead to specific types of behaviour, as well as result from and influence the interactions within a team. Emotions are an internal state of an individual, but also a phenomenon which develops between members of a group or organization. D. Armstrong (2006, p. 32) claims that emotional experience is very rarely located exclusively within a person's individual space, for it is a characteristic of interpersonal relations. If some emotions are experienced more often and more intensely than others, they start to give a dominant tone to the whole organization. P. Herriot (2001), similarly as D. Armstrong, claims, therefore, that one can talk of emotions "experienced" by the organization as a whole. J.M. George (2000) introduced the concept of "group affective tone," which describes coherent, uniform affective responses within a group. Then, E. Hatfield, J.T. Cacioppo and R.L. Rapson (1994, p. 5) propose the expression "emotional contagion," defined as the "tendency to automatically mimic and synchronize expressions, vocalizations, postures, and movements with those of another person and, consequently, to converge emotionally." This means that other people's emotions evoke the same or similar emotions in us, which usually happens beyond the control of consciousness.

Among the researchers, there has crystallized a view according to which collective emotions are something more than just the sum of emotions experienced by members by a given community (Ashkanasy, Hartel, Zerbe 2000, Lewis, Haviland-Jones 2005). The authors emphasize that emotional experience and its realization in the presence of others, who are also undergoing it, increase the intensity and permanence of the emotions felt. They reaffirm the assessment of an event, and thus also the justifiability of the emotions experienced.

In this context, knowledge about defence mechanisms, as unconscious or preconscious processes, which are aimed at protecting against experiencing unwanted, unpleasant emotional states, has been growing in importance.

Explanation of the functioning of groups and organizations in terms of anxiety and defence against it started in the 1950s thanks to the works of E. Jaques and I. Menzies-Lyth. E. Jaques (1951) asserted that social systems may support an individual in his or her psychological defence against anxiety, and individuals make unconscious use of the social system to this end. According to I. Menzies-Lyth (1988), the task of the social system is to contribute to avoidance of anxiety and internal conflicts, especially those that result from organizational tasks. As a result of the operation of defence mechanisms, difficult mental content (related to perceptions, thoughts, feelings, as well as acts of will) becomes distorted or weakened, as they defend against the experience of anxiety, as well as shame, uncertainty, or anger. Defence mechanisms may 
pertain to all mental processes, that is perceptions, thoughts, feelings, but also acts of will.

Individuals unconsciously form and reinforce those elements of the social system that support the most rigid and primary defence mechanisms, by creating common attitudes and 'defence techniques,' which are particularly clearly manifested in their approach to work. Subordination to defences in the conditions of collaboration influences individuals' feeling of personal identity and identification with a given team or organization. Every person unconsciously supports his or her own defence mechanisms, which leads to the formation of harmonized defence mechanisms within a group. At the same time, individual defence mechanisms, characteristic for specific organization members, are in turn supported and reinforced. The most commonly applied defence mechanisms include: suppression, repression, reaction formation, anticipation, isolation, undoing, projection, denial, idealization, sublimation, pseudo-altruism, as well as splitting, projective identification, and somatization (Fhaner 1996, pp. 106-107; see also Menzies 1960, Gabriel 2004, Stapley 2006).

The mechanism of splitting, projection and projective identification belong to primary defence mechanisms. The mechanisms form the earliest, operate at the unconscious level. They disturb adequate reacting to stimuli from the environment in the highest degree. Mechanisms like repression, reaction formulation, denial, isolation, and undoing facilitate adaptation to the conditions of reality, and possible damage concern the intrapsychic world of an individual, they are less directly disruptive for the effects of the work performed. Then, the mechanisms of compensation, suppression, anticipation, sublimation, and humour are listed among the most mature ones, as they help to cope with difficult psychological reality. Not only do they not lead to distortion of significant elements of the real world, but they are effective in supporting successful dealing with challenges that the world poses for an individual; they do not allow emotional states characterized by anxiety, shame or other unaccepted emotions to determine the behaviour of group members. At the same time, dominance of defence mechanisms, especially those of the lower order, the immature ones, lowers the performance quality, and thus the quality of the decision and choices made, the proposed solutions. 


\section{Organizational change - the managerial perspective}

Recognizing the correctness of the principle that situational context should be taken into account in studies concerning social phenomena, empirical research was implemented on the basis of direct and multiple contact with an organization, making use of participatory observation, free conversations with employees, semi structured interviews with managers and psychological questionnaires (OCI, MBTI, DSQ 40). Their main objective was to create a picture of organizational change from the perspective of the management. In addition, there was made an attempt at diagnosing the defence mechanisms that existed in the managers at the studied organization. The surveys were conducted within research project 4400/B/H03/2011/40, financed by the National Science Centre.

The results presented below refer only to the data from interviews and the questionnaire responses (DSQ 40), which identifies three main categories of defence mechanisms. These are:

- mature mechanisms (sublimation, humour, anticipation, suppression),

- neurotic mechanisms (magical thinking, pseudo-altruism, idealization, reaction formation),

- immature mechanisms (projection, passive aggression, acting out, isolation, devaluation, autistic fantasies, denial, displacement, dissociation, splitting, rationalization, somatization).

Interviews were conducted with ten managers, ten of whom were women, one was a man, while the DSQ 40 form was filled in by eight women who occupied managerial positions in one of departments of the organization.

The presented studies were carried out in the HR department of a limited company, listed on the stock exchange. Currently, the organization comprises more than fifty subsidiaries, which provide services in the area of human resource management. It specializes in seeking and recruitment of employees, career consultancy, outsourcing of personnel management functions and auxiliary processes in enterprises. Significant changes in the structure of the company took place in 2014, when intensive operations on foreign markets started, and simultaneously, the composition of the company's management board was significantly altered.

Interviews concerning the managers' opinions on organizational changes enabled development of a picture of the organization in the context of change, the main elements of which are presented in the table below. 
Table 1. Picture of organizational change - managers' opinions

\begin{tabular}{|c|c|c|}
\hline Category & Important content & Significance for the organization \\
\hline $\begin{array}{l}\text { Picture of changes } \\
\text { from managers' } \\
\text { perspective }\end{array}$ & $\begin{array}{l}\text { Change is a natural, dynamic } \\
\text { phenomenon; it is a continuous } \\
\text { process in the organization; } \\
\text { there is an awareness of } \\
\text { inherent diversity of change }\end{array}$ & $\begin{array}{l}\text { Positive - activity, openness to new ideas, } \\
\text { commitment; chance to be the market } \\
\text { leader } \\
\text { Negative - the threat of lack of time for } \\
\text { solidifying the changes; tiredness of some } \\
\text { employees; intensification of resistance to } \\
\text { change, when the feeling that the previous } \\
\text { changes were successful is missing (it is } \\
\text { important to establish a measures of that } \\
\text { 'success' or even progress) }\end{array}$ \\
\hline $\begin{array}{l}\text { Strengths of the } \\
\text { organization }\end{array}$ & $\begin{array}{l}\text { Zeal, commitment, especially } \\
\text { among the 'young' and } \\
\text { ambitious managers, } \\
\text { 'liveliness'; good interpersonal } \\
\text { relations are appreciated }\end{array}$ & $\begin{array}{l}\text { High potential, significant resources, } \\
\text { but a threat of fluctuation in case of } \\
\text { disappointments and frustration }\end{array}$ \\
\hline $\begin{array}{l}\text { Weaknesses of the } \\
\text { organization }\end{array}$ & $\begin{array}{l}\text { Division into 'new' and 'old' } \\
\text { managers; possible lack of } \\
\text { cohesion between companies } \\
\text { in different countries, but also } \\
\text { within Polish branches }\end{array}$ & $\begin{array}{l}\text { Wasting potential - poor utilization of } \\
\text { readiness for active operations (and } \\
\text { quick response to changes in the external } \\
\text { environment) }\end{array}$ \\
\hline Communication & $\begin{array}{l}\text { Poorly structured, spontaneous } \\
\text { rather than planned and } \\
\text { implemented with a purpose }\end{array}$ & $\begin{array}{l}\text { Uncertainty, lack of the feeling of influence } \\
\text { and security; tendency to create coteries, } \\
\text { division into 'them' - 'us'; splitting } \\
\text { (at various levels and areas of operations) }\end{array}$ \\
\hline
\end{tabular}

Source: own study

The figure below represents the distribution of defence mechanisms in three of the said categories (mature, neurotic and immature mechanisms), as well as their intensity in particular study subjects (assessment based on Andrews, Singh, Bond 1993, pp. 246-265).

The obtained results show that neurotic mechanisms are predominant among the studied managers (a slightly higher indicator compared to normalized indicators, based on Andrews, Singh, Bond 1993, pp. 246-265). On the other hand, the indicators of mechanisms belonging to mature defences remain in the lower bound of the norm. Immature mechanisms also take lower values within the norm. 


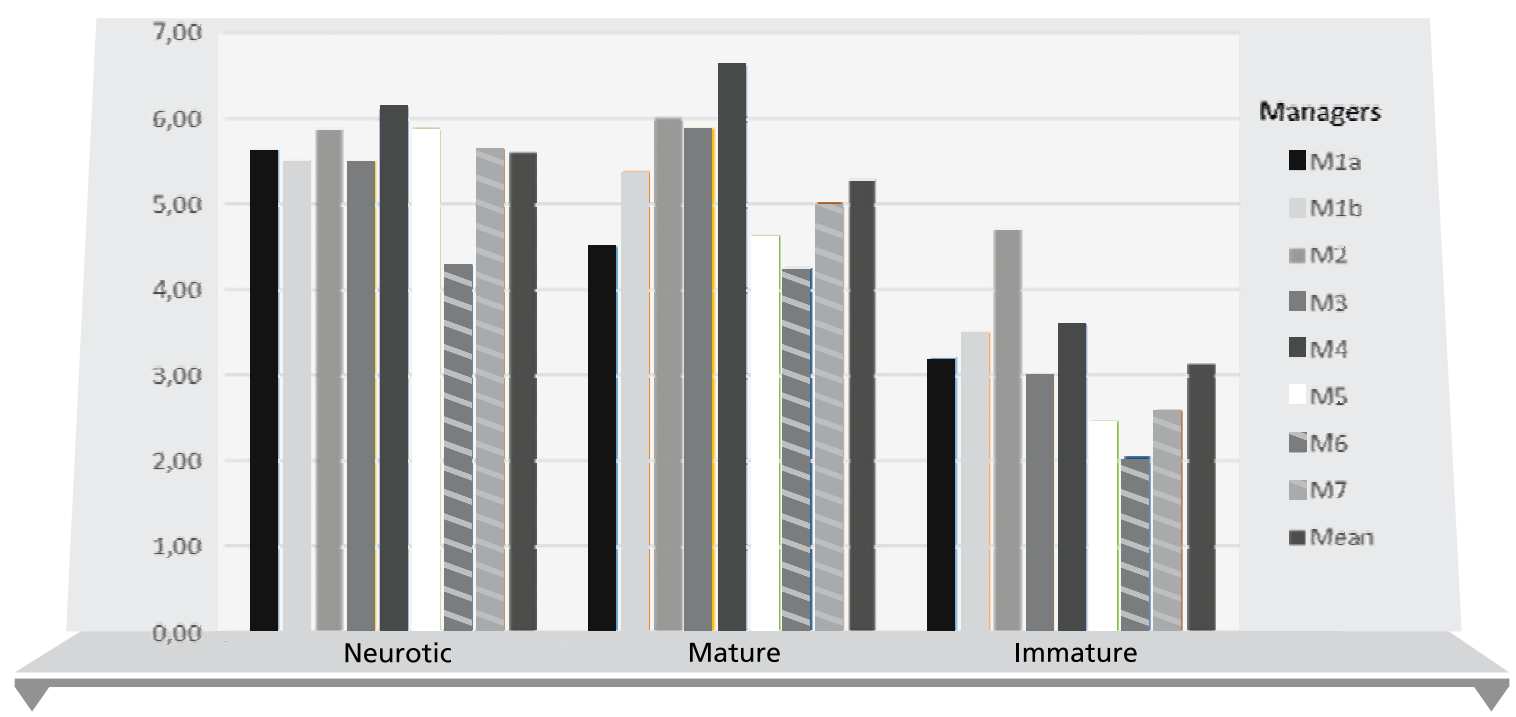

Figure 1. Managers' defence mechanisms

Source: own study

Among the study subjects, in terms of mature mechanisms, the highest values are taken by sublimation (values close to the norm), and the examined managers use suppression to a relatively lowest degree (indicator much lower than the normative data).

What stands out among the neurotic mechanisms is clear intensification of the idealization mechanism. Reaction formation is applied by the studied managers to a relatively lower degree Although the obtained results show that the values assigned to immature defence mechanisms fall within the bounds of the norm, qualitative analysis revealed that specific managers use some of the immature defence mechanisms in an extent much above the normative values. This pertains to mechanisms like denial, affect isolation, displacement (of aggression), somatization, but also projection, splitting and acting out (nonspecific release of tension). All the mechanisms, as mentioned above, help to cope with unpleasant and unwanted emotions, but unfortunately, they have a negative impact on the atmosphere in the workplace, as well as the final result of the work done, especially in the longterm perspective. 


\section{Conclusion}

Interviews with the managers made it possible to develop a picture of the change as a continuous process in the life of the organization, which is treated by the employees as a natural and inherently dynamic phenomenon. At the same time, the picture of the process of communication, especially in the conditions of organizational change, can hardly be considered satisfactory. The managers emphasize the key importance of communication in the organization, but they talk particularly a lot and in concert about the deficiencies of the communication process in the company. As causes of the unsatisfactory state of affairs, they indicated mainly lack of consistency in the application of procedures aimed at efficient communication. Here, ad hoc actions emerge, undertaken under the influence of temporary needs. Yet the most important aspect is the employees' conviction that the company has a division into 'better informed' ones and those who receive important information (plans, anticipated directions of change, time framework) at the last moment or, even worse, too late, as if 'after the deadline.' For if organization members do not have an opportunity to participate in the process of planning and preparation of change, they cannot experience the feeling of influence and control over the processes, which they participate in; nor do they have the feeling of impact on the formation of a new system of social defences, adjusted to the new situation. This increases the level of anxiety, leads to many anxieties; this inspires looking for information through reaching to the available sources. Unfortunately, such actions often get out of control of the change initiators, they introduce chaos and anxiety in the place of clear information and the desired order. As a result, there appears lack of trust, enmity and aggression instead of hope and commitment; fight instead of cooperation, passivity instead of commitment, distrust instead of openness.

The possibility to identify the defence mechanisms presented by the key organization members may help to optimize the strategies of acting in difficult situations, which certainly determine the actions related to implementation of organizational change. It is worthwhile to identify them also in the behaviour of other organization members in order to prevent negative consequences of dysfunctionality of individuals throughout the organization. Although identification of the defence mechanisms used in an organization and individual defence mechanisms, applied by specific organization members, will not replace concerted, targeted actions related to the process of implementation of change, it may significantly influence the efficiency of the process. 


\section{Summary}

\section{Psychodynamic Perspective of Organizational Change}

The complex processes and phenomena that are taking place in the contemporary world require new and adequate methods of acting also in the area of management. This means the need for a fresh approach to the process of organization development and change. This paper presents the key concepts stemming from the psychoanalytic approach to organization and management. Its main aim is to discuss the major categories (concepts) derived from psychoanalytic theories, which pertain to the issues related to organizational change. Theoretical considerations are complemented by presentation of the data collected during interviews with managers from the examined organization and identification of the defence mechanisms of representatives of the organization's management.

Key words: psychodynamic approach, organizational change, emotions, defence mechanisms.

\section{Streszczenie}

\section{Zmiana organizacyjna $w$ ujęciu psychodynamicznym}

Złożone procesy i zjawiska, zachodzące we współczesnym świecie wymagają nowych, adekwatnych metod działania także w obszarze zarządzania. Oznacza to potrzebą świeżego spojrzenia na procesy rozwoju i zmian $\mathrm{w}$ organizacji. Niniejszy artykuł zawiera kluczowe pojęcia wywodzące się z psychoanalitycznego podejścia do organizacji i zarządzania. Jego głównym celem jest omówienie głównych kategorii (pojęć) wywodzących się z teorii psychoanalitycznych, aodnoszącychsiędozagadnieńpowiązanych ze zjawiskiem zmian organizacyjnych. Rozważania o charakterze teoretycznym uzupełnia prezentacja danych zebranych $w$ trakcie wywiadów z menedżerami badanej organizacji oraz identyfikacja mechanizmów obronnych przedstawicieli kadry menedżerskiej organizacji.

\section{Słowa}

kluczowe: podejście psychodynamiczne, zmiana organizacyjna, emocje, mechanizmy obronne. 


\section{References:}

1. Andrews G., Singh M., Bond M. (1993), The Defense Style Questionnaire, "The Journal of Nervous and Mental Disease", Vol. 181, No. 4, pp. 246-256.

2. Armstrong D. (2006), Organization in the Mind, Karnac, New York.

3. Armstrong D, Rustin M. (ed.) (2015), Social Defences against anxiety, Karnac Books, London.

4. Ashkanasy N.M., Hartel C.E., Zerbe J.W. (eds.) (2000), Emotions in the Workplace: Theory, Research, and Practice, Quorum, Westport.

5. Bion W. (1961), Experiences in Groups, Basic Books, London.

6. Brunning H. (ed.) (2012), Psychoanalytic Reflections on Changing World, Karnac Books Ltd, London.

7. Czander W. M. (1993), The Psychodynamics of Work and Organizations, Guilford Press, New York.

8. de Board R. (2003), The psychoanalysis of organizations. A psychoanalytic approach to behaviour in groups and organizations, Brunner-Routledge, New York.

9. De Dreu C.K.W., West M., Fisher A., MacCurtain S. (2001), Emotions in Teams, w: S. Fineman (ed.), Emotion in Organizations, Sage, Newbury Park, 2001, pp. 199-213.

10. Fhaner S. (1996), Stownik Psychoanalizy, GWP, Gdańsk.

11. Freud Z. (1993), Tabu i totem, Wydawnictwo KR, Warszawa.

12. Gabriel Y. (2004), Organizations In Depth, Sage Publications, London.

13. Gabriel Y. (1983), Freud and Society, Routledge\&Kegan Paul, London.

14. George J.M., (2000), Emotions and leadership: the role of emotional intelligence, "Human Relations", 53 (8), pp. 1027-1055.

15. Hatfield E., Cacciopo J.T., Rapson R.L. (1994), Emotional Contagion, Cambridge University Press, New York.

16. Herriot P. (2001), Future Work and its Emotional Implications, w: S. Fineman S. (ed.), Emotion in Organizations, Sage, Newbury Park, CA.

17. Hirschhorn L. (1988), The Workplace Within. Psychodynamics of Organizational Life, The MIT press, London.

18. Jaques E. (1951), The Changing Culture of the Factory, Tavistock, London.

19. Kernberg O. (1998), Ideology, Conflict, and Leadership in Groups and Organizations, Yale University Press, New haven and London.

20. Kets de Vries M.F., Miller D. (1986), Personality, Culture, and Organization, "Academy of Management Review", Vol. 11, No. 2.

21. Lewis M., Haviland-Jones J.M.(eds) (2005), Psychologia emocji, GWP, Gdańsk.

22. Loewald H. (1980), Papers on psychoanalysis, Yale University Press, New Haven.

23. Menzies I.E.P. (1960), A case study in the functioning of social systems as a defense against anxiety, "Human Relations", 13, pp. 95-121. 
24. Menzies Lyth I. (1988), Containing anxiety in institutions: Selected essays, Free Association Books, London.

25. Miller E. (1993), From Dependence to Autonomy. Studies in Organizations and Change, Free Association Books, London.

26. Sievers B. (ed.) (2009), Psychoanalytic Studies of Organizations, Karnac Books Ltd, London.

27. Stapley L.F. (1996), The Personality of the Organization: A Psycho-Dynamic Explanation of Culture and Change, Free Association Books, London.

28. Stapley L.F. (2006), Individuals, Groups, and Organizations beneath the Surface, Karnac Books, London.

29. Vansina L.S. (2013), Humanness in Organisations. A Psychodynamic Contribution, Karnac Books Ltd, London. 